\title{
FENOMENA PEMBUSURAN DIKALANGAN REMAJA
}

\author{
Ria Safaria Sadif \\ Prodi Bimbingan Konseling, Fakultas Keguruan dan Ilmu Pendidikan \\ Universitas Muhammadiyah Buton, Jl. Betoambari No. 36 Baubau. \\ Email: tom_riano@yahoo.com
}

\begin{abstract}
Abstrak
Penelitian ini bertujuan untuk mengetahui fenomena pembusuran dikalangan remaja. Metode penelitian yang digunakan dalam penelitian ini menggunakan pendekatan kualitatif. Subjek penelitian primer dalam penelitian berjumlah 2 anak remaja (pelaku pembusuran), serta subjek penelitian sekunder 4 anak remaja (kepemilikan busur). Hasil penelitian menunjukan bahwa subjek penelitian memiliki rentang usia masa remaja, masih berstatus sebagai pelajar di SMP dan SMA kota Baubau. Intensitas pertemuan orang tua dengan subjek penelitian dapat dikatakan kurang baik, karena kebanyakan orang tua bekerja di luar rumah dengan rentang waktu yang cukup lama. Rata-rata subjek mencari penghasilan juga ketika pulang sekolah dari sore hingga malam hari. Dengan demikian intensitas untuk bertemu dan berkomunikasi antar anak dan orang tua cukup minim terjadi. Motivasi remaja melakukan pembusuran, yaitu motif intrinsik dan motif ekstrinsik. Faktor-faktor penyebab pelaku melakukan pembusuran di kota Baubau yaitu faktor internal yang terdiri dari ketersinggungan antar kelompok dan adanya perasaan terancam, serta faktor eksternal yang terdiri dari faktor keluarga seperti kurangnya perhatian. Cara mendapatkan busur yaitu dengan cara membuat sendiri.
\end{abstract}

Kata kunci: pembusuran, remaja.

\begin{abstract}
This study aims to determine the phenomenon of eviction among teenagers. The research method used in this study uses a qualitative approach. The primary research subjects in the study were 2 adolescents (perpetrators of eviction), and secondary research subjects 4 adolescents (bow ownership). The results of the study showed that the study subjects had a range of adolescence, still in the status of students in the Baubau city middle and high school. The intensity of meeting parents with research subjects can be said to be less good, because most parents work outside the home with a fairly long span of time. The average subject is also looking for income when returning home from evening to night. Thus the intensity of meeting and communicating between children and parents is quite minimal. The motivation of adolescents to do eviction, namely intrinsic motives and extrinsic motives. The factors that caused the perpetrators to carry out the eviction in Baubau city were internal factors consisting of offense between groups and the feeling of being threatened, as well as external factors consisting of family factors such as lack of attention. How to get a bow that is by making it yourself.
\end{abstract}

Keywords: eviction, teenagers. 


\section{SANG PENCERAH}

Volume 4, Nomor 2, Agustus 2018, Hlm. 51-56

Ria Safaria Sadif: Fenomena Pembusuran Dikalangan Remaja

\section{Pendahuluan}

Istilah remaja (adolescence) berasal dari kata Latin adolescre yang berarti tumbuh atau tumbuh menjadi dewasa.(Hurlock, 1980). Dengan kata lain, Dariyo menyatakan bahwa remaja (adolescence) adalah masa transisi atau peralihan dari masa kanakkanak menuju masa dewasa. Masa remaja ditandai dengan adanya perubahan aspek fisik, psikis, dan psikososial. Dengan mengutip Thornburg, ia menggolongkan remaja kedalam tiga tahap, yaitu remaja awal (usia 13-14 tahun), remaja tengah (usia 15-17 tahun), remaja akhir (18-21 tahun). Remaja tidak memiliki tempat yang jelas, mereka tidak termasuk dalam kategori anakanak dan tidak juga dikatakan dalam kategori dewasa (Agoes, 2004).

Kenakalan yang terjadi pada masyarakat sangat berkaitan atau identik dengan para remaja, oleh karena itu perlu kita ketahui jenjang dimana para remaja banyak melakukan aksi kenakalan yang dapat meresahkan lingkungan dimana remaja berada dan tinggal. Dalam kehidupan para remaja sering kali diselingi hal-hal yang negatif dalam rangka penyesuaian dengan lingkungan sekitar baik lingkungan dengan teman-temannya di sekolah maupun lingkungan pada saat dia di rumah. Hal-hal tersebut dapat berbentuk positif hingga negatif yang sering kita sebut dengan kenakalan remaja. Kenakalan remaja itu sendiri merupakan perbuatan pelanggaran norma-norma baik norma hukum maupun norma sosial (Agoes, 2004).

Kenakalan remaja dalam studi masalah sosial dapat dikategorikan ke dalam perilaku menyimpang. Dalam perspektif perilaku menyimpang masalah sosial terjadi karena terdapat penyimpangan perilaku dari berbagai aturan-aturan sosial ataupun dari nilai dan norma sosial yang berlaku. Perilaku menyimpang dapat dianggap sebagai sumber masalah karena dapat membahayakan tegaknya sistem sosial. Penggunaan konsep perilaku menyimpang secara tersirat mengandung makna bahwa ada jalur baku yang harus ditempuh. Perilaku yang tidak melalui jalur tesebut berarti telah menyimpang (Suwarniyati Sartono, 1985).

Kasus pembusuran yang terjadi di kota Baubau telah mengarah kepada tindakan melanggar hukum atau kegiatan kriminal sebagai masalah sosial yang terjadi di kalangan generasi muda. Sebagaimana dijelaskan oleh Soerjono (2007), masalah generasi muda pada umumnya ditandai oleh dua ciri yang berlawanan, yakni keinginan untuk melawan dan sikap apatis. Beberapa sikap melawan, misalnya, dalam bentuk radikalisme dan delinkuensi. Sedangkan sikap apatis seperti penyesuaian yang membabibuta terhadap ukuran moral. Persoalan ini dialami oleh kelompok usia remaja, yakni suatu kelompok yang jika dilihat secara fisik bisa disebut telah matang, tetapi belum bisa disebut matang bila dilihat secara sosial. Kelompok ini perlu banyak belajar mengenai nilai dan norma-norma masyarakatnya.

Fenomena pembusuran yang ada di Kota Baubau terjadi pada beberapa wilayah Kota Baubau khususnya di daerah Tanah Abang - Tomba, Wameo/Tarafu - Bonebone. Konflik antar wilayah ini sudah sangat lama terjadi, bahkan awal mula perselisihan tidak diketahui oleh para pelaku pembusuran saat ini. Namun, dendam yang masih tersimpan hingga saat ini membuat mudah terjadi konflik antar wilayah tersebut. Salah satu kasus pembusuran yang telah terjadi di kota Baubau terjadi Pada Hari Senin, 7 November 2016 sekitar jam 22.10 WITA bertempat di belakang Losmen Salim Kelurahan Bataraguru Kec. Wolio Kota baubau. Bobi (masyarakat Bataraguru) umur 18 tahun, alamat Kel. Bataraguru Kec. Wolio Kota Baubau terkena busur yang diduga dilakukan oleh Dani. Setelah melakukan pembusuran Dani melarikan diri menggunakan sepeda motor. Namun, saat melarikan diri pelaku mengalami kecelakaan 


\section{SANG PENCERAH}

Volume 4, Nomor 2, Agustus 2018, Hlm. 51-56

\section{Ria Safaria Sadif: Fenomena Pembusuran Dikalangan Remaja}

yang menyebabkan Dani meninggal dunia (www.laporannews.com). Berdasarkan deskripsi di atas, fokus penelitian ini adalah bagaimanakah fenomena pembusuran dikalangan remaja?

Penelitian ini bertujuan untuk mengetahui fenomena pembusuran dikalangan remaja.

\section{Metode Penelitian}

\section{Pendekatan Penelitian}

Penelitian ini menggunakan pendekatan kualitatif yaitu prosedur penelitian yang menghasilkan data deskriptif berupa katakata tertulis atau dari orang-orang dan perilaku yang dapat diamati.

\section{Subjek Penelitian}

Pada penelitian ini, subjek penelitian primer berjumlah 2 anak remaja (pelaku pembusuran) berusia 13 dan 14 tahun, serta subjek penelitian sekunder 4 anak remaja (kepemilikan busur) berusia 13, 15, 18, dan 20 tahun serta salah satu orang tua pelaku pembusuran.

\section{Pembahasan}

\section{Gambaran Umum Subjek Penelitian}

Selang umur para pelaku pembusuran berkisar antara 13-20 tahun yang dapat diklasifikasikan sebagai masa remaja, yaitu masa remaja berada dalam kondisi kebingungan karena masih ragu harus memilih yang mana, peka atau peduli, ramai-ramai atau sendiri, optimis atau pesimis, dan sebagainya. Rata-rata Subjek masih berstatus murid di SMP hingga SMA di kota Baubau. Kondisi hubungan pelaku pembusuran dengan orang tua beragam. Beberapa subjek memiliki orang tua yang lengkap dan tinggal bersama, ada yang lengkap namun kedua orang tua merantau mencari pekerjaan di luar kota Baubau, serta yang lainnya kedua orang tua subjek sudah bercerai dan tinggal dengan salah satu orang tua subjek.

Intensitas pertemuan orang tua dengan subjek penelitian dapat dikatakan kurang baik, karena kebanyakan orang tua bekerja di luar rumah dengan rentang waktu yang cukup lama. Rata-rata subjek mencari penghasilan juga ketika pulang sekolah dari sore hingga malam hari. Dengan demikian intensitas untuk bertemu dan berkomunikasi antar anak dan orang tua cukup minim terjadi.

\section{Gambaran Umum Motivasi Remaja Melakukan Pembusuran}

Saat melakukan aksi pembusuran, para pelaku selalu beramai-ramai atau dalam sekelompok. Motivasi berasal dari kata lain "Movere" yang berarti dorongan atau dalam bahasa Inggris to move. Motif diartikan sebagai kekuatan yang terdapat dalam diri organisme yang mendorong untuk berbuat. Motif tidak berdiri sendiri, tetapi saling berkaitan dengan faktor-faktor lain, baik faktor eksternal, maupun faktor internal.

Motif Intrinsik merupakan faktor dari dalam, faktor dimana adanya dorongan dari dalam diri seseorang itu sendiri. Dalam faktor internal ini dapat di peroleh salah satu penyebab melakukan pembusuran adalah sikap remaja yang ingin di perhatikan oleh kelompok lain atau remaja yang mencari kenyamanan dalam kelompok.

Motif Eksterinsik merupakan faktor dari luar diri individu yang berpengaruh terhadap perkembangan diri seseorang, terutama faktor lingkungan baik itu lingkungan dimana remaja dibesarkan maupun dengan siapa remaja itu berteman, termasuk rendahnya tingkat perhatian keluarga (orang tua) terhadap aktivitas anak di luar rumah sehingga remaja mudah terpengaruh terhadap pengaruh di luar. 


\section{SANG PENCERAH}

Volume 4, Nomor 2, Agustus 2018, Hlm. 51-56

Ria Safaria Sadif: Fenomena Pembusuran Dikalangan Remaja

\section{Faktor-faktor Penyebab Melakukan Pembusuran}

Adapun

menyebabkan

faktor-faktor yang

pembusuran, yaitu (1)

terhadap musuh; (2) Merasa tersinggung dengan ucapan atau panggilan-panggilan menggunakan nama hewan; dan (3) Adanya perintah atau ancaman dari orang dewasa dalam kelompok.

\section{Gambaran Umum Cara Mendapatkan Busur}

Kasus pembusuran sudah lebih dulu terjadi di kota Makassar. Bentuk busur yang digunakan dalam kasus-kasus di kota Makassar sama dengan busur yang digunakan di kota Baubau. Berdasarkan hasil wawancara, para pelaku melihat tutorial pembuatan busur melalui Youtube dan dilatih oleh teman subjek yang lebih dulu mengusai cara membuat busur. Ada pun bahan-bahan yang diperlukan oleh subjek dalam pembuatan busur diperoleh dari paku yang ditemukan di jalan, atau besi kecil yang tidak terpakai, sedangkan bahan karet yang diperlukan diperoleh dari kateter bekas pakai. Kateter tersebut mereka dapatkan dari limbah yang di buang di sekitar Rumah Sakit Umum Daerah.

Pembuatan busur dilakukan di bengkel di sekitar rumah salah satu subjek, di halaman rumah subjek atau di tempattempat yang tidak banyak dilalui oleh orang lain. Setelah mendapatkan busur atau setelah busur yang subjek buat telah jadi, maka subjek akan berlatih menggunakan busur tersebut di pohon pisang atau hewan, seperti tikus dan anjing.

\section{Gambaran Umum Kriteria Korban Pembusuran}

Para pelaku pembusuran di kota Baubau tidak memiliki kriteria khusus dalam menargetkan korban. Mereka hanya mencari korban yang merupakan warga yang tinggal di lingkungan musuh mereka.
Kenakalan yang terjadi pada masyarakat sangat berkaitan atau identik dengan para remaja, oleh karena itu perlu kita ketahui jenjang dimana para remaja banyak melakukan aksi kenakalan yang dapat meresahkan lingkungan dimana remaja berada dan tinggal. Dalam kehidupan para remaja sering kali diselingi hal-hal yang negatif dalam rangka penyesuaian dengan lingkungan sekitar baik lingkungan dengan teman-temannya di sekolah maupun lingkungan pada saat dia di rumah. Hal-hal tersebut dapat berbentuk positif hingga negatif yang sering kita sebut dengan kenakalan remaja. Kenakalan remaja itu sendiri merupakan perbuatan pelanggaran norma-norma baik norma hukum maupun norma sosial (Agoes dariyo, 2004).

Tindakan agresi juga termasuk kedalam kenakalan remaja baik secara pribadi maupun kelompok. Pembusuran yang dilakukan oleh remaja dapat digolongan termasuk kedalam tindakan agresi atau perilaku agresi. Dalam teori pendidikan menurut Widiastuti (2002) bahwa perilaku agresi adalah setiap bentuk perilaku yang diarahkan untuk merusak atau melukai orang lain. Selain perilaku, agresi juga mencakup maksud dan tindakan seseorang untuk merusak atau melukai orang lain yang dapat dilakukan secara fisik maupun verbal.

Perilaku agresi yang dilakukan oleh remaja menimbulkan dampak negatif yang tidak baik bagi dirinya sendiri dan orang lain, serta lingkungannya sekitarnya. Menurut Sarwono (1989), perilaku agresi dikategorikan menjadi empat bentuk, yaitu (1) Perilaku agresi yang menimbulkan korban fisik pada orang lain, seperti: perkelahian, perkosaan, perampokan, pembunuhan, dan lain-lain; (2) Perilaku agresi yang menimbulkan korban materi, seperti: perusakan, pencurian, pencopetan, pemerasan, dan lain-lain; (3) Perilaku agresi yang tidak menimbulkan korban di pihak 


\section{SANG PENCERAH}

Volume 4, Nomor 2, Agustus 2018, Hlm. 51-56

\section{Ria Safaria Sadif: Fenomena Pembusuran Dikalangan Remaja}

orang lain, seperti: pelacuran, penyalahgunaan obat, hubungan seks bebas; dan (4) Perilaku agresi yang melawan status, seperti: mengingkari status anak sebagai pelajar dengan cara membolos, "minggat" dari rumah, membantah perintah.

Sementara menurut Hurlock (1980), perilaku agresi yang dilakukan remaja terbagi dalam empat bentuk, yaitu:

1. Perilaku yang menyakiti diri sendiri dan orang lain.

2. Perilaku yang membahayakan hak milik orang lain, seperti: merampas, dan lainnya.

3. Perilaku yang tidak terkendali, yaitu perilaku yang tidak mematuhi orangtua dan guru seperti: membolos, mengendarai kendaran dengan tanpa surat izin, dan kabur dari rumah.

4. Perilaku yang membahayakan diri sendiri dan orang lain, seperti: mengendarai motor dengan kecepatan tinggi, memperkosa dan menggunakan senjata tajam.

Salah satu karakteristik masa remaja dalam Hurlock (1980) sebagai usia bermasalah dan masa mencari identitas diri dan mencari identitas. Usia bermasalah pada masa remaja; masalah yang dihadapi oleh remaja selalu di selesaikan oleh orang tua dan orang yang lebih tua dari remaja. Remaja tidak berpengalaman mengatasi masalahnya sendiri atau sering kali menolak untuk menerima bantuan sehingga masalah yang dihadapinya tidak terselesaikan dengan baik. Masa mencari identitas: masa penyesuaian diri dengan kelompok/geng. Salah satu cara untuk mengangkat diri sendiri menggunakan simbol status. Dengan masuk dalam kelompok pembusuran, para remaja merasa bangga dan dengan melakukan aksi busur seseorang dapat diterima dengan baik di dalam geng tersebut. Karena dianggap memiliki loyalitas dalam pertemanan dan geng.
Salah satu tugas perkembangan masa remaja adalah menemukan model yang dijadikan identitasnya. Menurut teori behavioristik Albert Bandura, kebanyakan perilaku manusia dipelajari dengan mencontoh orang lain. Modelling, manusia mengobservasi perilaku model dan kemudian mengulang perilaku tersebut. Maraknya kasus pembusuran bisa diakibatkan karena model yang menjadi contoh dari pelaku pembusur adalah faktor lingkungan: teman sebaya/teman geng yang selalu diamatinya, atau ada proses belajar yang didapatkan oleh geng tersebut dari berita-berita yang ditayang di TV, youtube atau media masa sehingga menginspirasikan mereka untuk melakukan hal yang sama dalam menyelesaikan masalah.

Faktor keluarga: bila di dalam keluarga selalu ada kekerasan, maka anak akan mencontoh perilaku-perilaku tersebut. Baik dalam menyelesaikan masalah mau pun dalam pengontrolan emosi. dan juga jika di dalam rumah tidak ada aturan-aturan yang diberlakukan bagi anak, maka anak cenderung lebih bebas dalam bertingkah laku tanpa memikirkan atau mematuhi aturan-aturan atau norma-norma yang berlaku di masyarakat.

\section{Simpulan}

Simpulan penelitian ini bahwa gambaran umum subjek penelitian memiliki rentang usia masa remaja, masih berstatus sebagai pelajar di SMP dan SMA kota Baubau. Intensitas pertemuan orang tua dengan subjek penelitian dapat dikatakan kurang baik, karena kebanyakan orang tua bekerja di luar rumah dengan rentang waktu yang cukup lama. Rata-rata subjek mencari penghasilan juga ketika pulang sekolah dari sore hingga malam hari. Dengan demikian intensitas untuk bertemu dan berkomunikasi antar anak dan orang tua cukup minim terjadi. Gambaran umum motivasi remaja melakukan pembusuran, yaitu motif 


\section{SANG PENCERAH}

Volume 4, Nomor 2, Agustus 2018, Hlm. 51-56

\section{Ria Safaria Sadif: Fenomena Pembusuran Dikalangan Remaja}

intrinsik dan motif ekstrinsik. Faktor-faktor penyebab pelaku melakukan pembusuran di kota Baubau yaitu faktor internal yang terdiri dari ketersinggungan antar kelompok dan adanya perasaan terancam, serta faktor eksternal yang terdiri dari faktor keluarga seperti kurangnya perhatian. Kurang perhatian yang dimaksud ialah orang tua yang sibuk sehingga kurang memperhatikan, tidak melakukan pengawasan terhadap anaknya serta minimnya komunikasi yang terjalin dalam keluarga. Gambaran umum cara mendapatkan busur yaitu dengan cara membuat sendiri. Pelaku mempelajari cara pembuatannya melalui tutorial di Youtube dan mendapatkan arahan dari teman yang mampu membuat busur. Bahan diperoleh dari limbah Rumah Sakit dan besi yang tidak terpakai. Tidak ada kriteria umum yang menjadi target korban pembusuran.

\section{Daftar Pustaka}

Agoes, Dariyo. 2004. Psikologi Perkembangan Remaja. Jakarta: Ghalia Indonesia.

Hurlock. 1980. Psikologi Perkembangan. Jakarta: Erlangga.

Sarwono, Sarlito Wirawan. 1989. Psikologi Remaja. Jakarta: CV Rajawali.

Soerjono, soekanto. 2007. Sosiologi Suatu Pengantar. Jakarta: PT Raja Grapindo.

Suwarniyati Sartono, 1985. Pengurangan Sikap Masyarakat terhadap Kenakalan Remaja di DKI Jakarta. laporan penelitian UI. Jakarta: Persada.
Perang Busur Kembali Terjadi di Baubau. Diakses pada tanggal 9 November 2016. Dari http://www.laporannews.com

Widiastuti, Wahyu. 2002. Dampak Adegan Kekerasan di Televisi Terhadap Perilaku Agresif Remaja Perkotaan. Bengkulu: Fakultas Ilmu Sosial dan Politik, Universitas Bengkulu. 